\title{
Concentration of selected low molecular-weight proteins in urine - a retrospective analysis of chronic kidney disease among HIV patients receiving antiretroviral therapy
}

\author{
Zofia Marchewka ${ }^{1}$, Beata Szymańska ${ }^{1}$, Justyna Domagała ${ }^{1}$, Bartosz Szetela $^{2}$, Brygida Knysz ${ }^{2}$, Agnieszka Piwowar \\ ${ }^{1}$ Department of Toxicology, Faculty of Pharmacy, Wroclaw Medical University, Poland \\ ${ }^{2}$ Department of Infectious Diseases, Liver Disease and Acquired Immune Deficiencies, Wroclaw Medical University, Poland
}

\begin{abstract}
Introduction: Human immunodeficiency virus (HIV) infection remains an important health problem despite the fact that combined antiretroviral therapy (cART) prolongs life and protects against acquired immunodeficiency syndrome (AIDS). Chronic kidney disease is an important cause of mortality among HIV patients, co-monitoring of renal function and modifying factors such as cART require constant analysis. The aim of this study was a retrospective analysis of renal function among HIVinfected and cART-treated patients by measuring urine concentrations of chosen low molecular weight proteins (LMWP) as biomarkers of kidney dysfunction: retinol-binding protein (RBP), $\beta_{2}$-microglobulin $\left(\beta_{2} \mathrm{M}\right)$, and neutrophil gelatinase-associated lipocalin (NGAL). The results were compared with those obtained seven years earlier (in 2011) in the same patients.
\end{abstract}

Material and methods: Urine samples from 34 patients of Wroclaw outpatient HIV Clinic and from $30 \mathrm{HIV}$-negative individuals with no renal or any other disease were examined. Concentrations of LMWP were measured by immunoenzymatic ELISA tests.

Results: Compared to 2011, reduction in the concentration of excreted LMWP was observed. No deleterious renal effect of tenofovir could be shown; however, most patients were receiving the new prodrug (TAF) of reduced nephrotoxicity. Positive correlation between serum creatinine and urine $\beta_{2} \mathrm{M}$ was shown and negative correlation between eGFR and urine RBP. Coexistence of HCV infection and the number of T CD4(+) cells also correlated with the concentration of the biomarkers.

Conclusions: This retrospective analysis shows a need for long-term renal function monitoring as well as other factors that may influence renal function among HIV patients. RBP, NGAL, and $\beta_{2} \mathrm{M}$ have been confirmed to be useful biomarkers for early detection of renal dysfunction.

HIV AIDS Rev 2019; 18, 1: 7-13 DOI: https://doi.org/10.5114/hivar.2019.84232

Key words: HIV, chronic kidney disease, antiretroviral therapy, low molecular weight proteins.

Address for correspondence: Dr. Bartosz Szetela, Department of Infectious Diseases, Liver Disease and Acquired Immune Deficiencies, Wroclaw Medical University, 5 Koszarowa St., 50-324 Wrocław, Poland, e-mail: bartekszetela@poczta.fm
Article history:

Received: 08.02.2019

Received in revised form: 08.02.2019

Accepted: 11.02.2019

Available online: 28.03.2019
International Journal of HIV-Related Problems

HIV \& AIDS

R e v i e w 


\section{Introduction}

Human immunodeficiency virus (HIV) infection remains an important health problem for a wide group of patients both in Poland and all over the world. Lack of antiretroviral therapy may lead to acquired immune deficiency syndrome (AIDS), while modern combined and continuously improved antiretroviral therapy (cART) reduces HIV viral load to undetectable levels, stops disease progression, and reduces mortality $[1,2]$. Despite many benefits of cART, it can also have numerous side effects. Compared to noninfected individuals, HIV patients have increased incidence of cardiovascular disease, diabetes, non-AIDS cancers, and renal disease, all significant causes of mortality, partly due to cART regimens and partly due to direct HIV replication [3]. Additionally, HIV patients are at a higher risk of being co-infected with $\mathrm{HBV}$ and $\mathrm{HCV}$ due to shared route of transmission [4], and such coinfection increases the risk of renal HIV-associated disease [5].

Despite many years of cART availability, renal disease still is one of the most common pathologies associated with HIV infection. It concerns chronic kidney disease (CKD) and end-stage renal disease (ESRD), which still occur more often among HIV-positive than -negative patients, although currently reduction of HIV incidence is observed [6]. Other diseases caused directly by HIV include HIV-associated nephropathy (HIVAN) [7, 8], thrombotic microangiopathy $[9,10]$, and HIV immune complex kidney disease (HIVICK) [10,11]. Renal dysfunction in HIV patients can also be caused by concomitant diseases like hypertension, diabetes, dyslipidaemias, or opportunistic infections $[12,13]$.

Antiretroviral therapy itself, despite its benefits, can have numerous side effects, nephropathy being an important problem $[1,14]$. Additional risk factors for CKD include substances used during chemsex and medications used to enhance bioavailability of antiretrovirals [15]. Primary nephropathy can be even more important when patients are infected with HIV. Up to $30 \%$ of HIV patients have been estimated to have renal dysfunction. These dysfunctions are of serious clinical concern because they can be asymptomatic for many years and hence go undiagnosed, in effect leading to ESRD [16].

The importance of kidney disease in HIV patients can be summarised by the number and range of different factors significantly influencing renal function in this group. Hence, new specific biomarkers for early CKD detection are being sought to stop deterioration of renal function in these patients [17]. The following urine low molecular weight proteins (LMWPs) have been found to be useful as diagnostic and/or therapeutic markers of renal dysfunction: neutrophil-gelatinase-associated lipocalin (NGAL), retinol binding protein $(\mathrm{RBP})$, and $\beta_{2}$-microglobulin $\left(\beta_{2} \mathrm{M}\right)$. They are more sensitive and more specific compared to other routinely used biomarkers, such as serum creatinine or estimated glomerular filtration rate (eGFR), and non-invasive urine sampling increases its usefulness $[18,19]$. NGAL is a protein of $25 \mathrm{kDa}$ covalently bound to human neutrophils. It is a sensitive and specific marker for early renal dysfunction. Measurement of NGAL concentration in urine allows the detection of acute kidney injury (AKI) after cardiosurgical procedures, radiocontrast use, or septic shock [20-24]. $\beta_{2} \mathrm{M}$ and retinol binding protein are proteins of molecular weight of $12 \mathrm{kDa}$ and $21 \mathrm{kDa}$, respectively. They are freely filtered and completely reabsorbed, so even minute renal impairment (renal tubule) is manifested by increases in their urine concentration [25-27].

The aim of this study was to retrospectively analyse renal function in HIV patients receiving antiretroviral therapy, by measuring the urine concentration of chosen low molecular weight proteins as useful biomarkers of renal dysfunction: $\mathrm{RBP}, \mathrm{NGAL}$, and $\beta_{2} \mathrm{M}$. Urine excretion of these biomarkers was analysed versus applied cART, serum creatinine, eGFR value, HCV coinfection, current T CD4(+) cell count, and route of HIV infection. Current results were then compared with the results obtained from the same group of patients in 2011 as well as a control group.

\section{Material and methods}

Urine samples were taken from 34 HIV-infected patients treated at Wroclaw outpatient HIV clinic. The control group included healthy volunteers with no other urinary tract abnormalities (excluded on clinical and laboratory exam). The characteristics of both groups are shown in Table 1 . Information on $\mathrm{HCV}$ infection (presence of anti-HCV antibodies), antiretroviral regimen, serum creatinine, eGFR, route of HIV infection, and T CD4(+) cell count was collected from medical records. There were no significant differences between these groups.

Morning urine samples were collected in polyethylene cups containing no preservatives. Morphotic fraction was separated by centrifugation at $1480 \mathrm{x} g$ for 10 minutes. Samples were then kept frozen at $-80^{\circ} \mathrm{C}$ until analyses were performed. The approval of the Local Bioethics Committee of Wrocław Medical University was obtained (Nr-12/2018).

Urine concentrations of RBP, NGAL, and $\beta_{2}$ M were measured using ELISA immunoenzymatic methods according to the manufacturers' procedures (Demeditec, Immundiagnostik). Urinary creatinine concentration was measured using Jaffe method (reaction of picric acid and creatinine under acidic conditions) allowing the calculation of the concentration of low molecular weight proteins per milligram of creatinine in urine. The number of T CD4(+) cells [cells/ $\mu \mathrm{l}]$ was measured by flow-cytometry using a FACScan (Becton-Dickinson) (Table 1).

Statistical analysis was performed using STATISTICA 13.1 PL software. Data distribution was checked with Kolmogorov-Smirnov and Lilliefors tests. Parametric variables were compared using Studen's $t$-test and non-parametric variables with $U$ Mann-Whitney test. Correlation analysis was made using Pearson's test for parametric variables and Spearman's test for non-parametric variables. $P$ values were defined as statistically significant if $\leq 0.05$. 
Table 1. Characteristics of the study and control groups

\begin{tabular}{|c|c|c|}
\hline Group characteristics & Patients, $n(\%)$ & Control group, $n(\%)$ \\
\hline Number of patients & 34 & 30 \\
\hline Men & $28(82)$ & $24(80)$ \\
\hline Women & $6(18)$ & $6(20)$ \\
\hline Mean age (years, age range) & $50(35-67)$ & $50(32-72)$ \\
\hline Tenofovir alafenamide (TAF) & $19(56)$ & - \\
\hline Tenofovir disoproxil fumarate (TDF) & $3(9)$ & - \\
\hline HCV co-infection & $17(50)$ & - \\
\hline Normal range eGFR $\left(>90 \mathrm{ml} / \mathrm{min} / 1.73 \mathrm{~m}^{2}\right)$ & $13(38)$ & - \\
\hline CD4(+) T cells $(\geq 500$ cells $/ \mu \mathrm{l})$ & $28(82)$ & - \\
\hline \multicolumn{3}{|l|}{ Route of infection } \\
\hline Intravenous drug use (IDU) & $16(47)$ & - \\
\hline Men having sex with men (MSM) & $12(35)$ & - \\
\hline Heterosexual sex (HTX) & $6(18)$ & - \\
\hline
\end{tabular}

\section{Results}

The values of the low molecular weight proteins in the study and control groups are presented in Table 2. Mean concentrations of all examined parameters were higher in the HIV-positive group compared to the controls, but only NGAL had statistically higher values $(p=0.009)$ (Table 2$)$.

The obtained results were then compared with protein concentrations in the same patients examined in 2011. Mean concentrations of all markers were higher in 2011: RBP 200.76 ng/mg cr., NGAL $26.57 \mathrm{ng} / \mathrm{mg} \mathrm{cr}$., and $\beta_{2} \mathrm{M} 0.90$ $\mu \mathrm{g} / \mathrm{mg} \mathrm{cr}$, with RBP and $\beta_{2} \mathrm{M}$ reaching statistical significance ( $p=0.037$ and $p=0.010$, respectively). Additionally, RBP levels in 2011 and 2018 correlated positively $(R=0.5722$; $p=0.0004$ ).

In 2018 the analysed patients were divided into two groups to ascertain the influence of antiretroviral therapy on the level of low molecular weight proteins excreted with urine. Group I included 22 patients receiving regimens containing tenofovir prodrug, either tenofovir disoproxil fumarate (TDF) or tenofovir alafenamide (TAF), and their mean age was 49 years. Group II included 12 patients receiving regimens containing lamivudine and abacavir, and their mean age was 53 years. In both groups the most common third drug was darunavir/ritonavir or dolutegravir. Mean concentrations of protein markers in urine, serum creatinine, and eGFR in these two groups are presented in Table 3. Higher concentrations of all LMWP biomarkers were seen in group II (Table 3 ).

High (but statistically not significant) LMWP concentrations, lower eGFR, and higher serum creatinine concentration in the group not receiving tenofovir suggest that these regimens impair renal function. It has further been confirmed by statistically important high correlation between serum creatinine and urine $\beta_{2} \mathrm{M}$ concentrations in group II $(R=0.6325 ; p=0.027)$.
Table 2. Protein markers concentrations in the study and control groups

\begin{tabular}{l|c|c|c}
\hline & $\begin{array}{c}\text { RBP } \\
{[\mathrm{ng} / \mathrm{mg} \mathrm{cr} .]}\end{array}$ & $\begin{array}{c}\text { NGAL } \\
{[\mathrm{ng} / \mathrm{mg} \mathrm{cr} .]}\end{array}$ & $\begin{array}{c}\boldsymbol{\beta}_{2} \mathbf{M} \\
{[\mu \mathrm{g} / \mathrm{mg} \mathrm{cr} .]}\end{array}$ \\
\hline \multicolumn{3}{|c}{ Study group } \\
\hline $\mathrm{X}$ & 130.36 & $20.32^{*}$ & 0.77 \\
\hline$n$ & 139.12 & 22.99 & 1.47 \\
\hline \multicolumn{3}{|c}{ Control group } \\
\hline $\mathrm{X}$ & 34 & 8.83 & 34 \\
\hline SD & 38.82 & 5.81 & 0.17 \\
\hline$n$ & 30 & 30 & 30 \\
\hline${ }^{*}$ Statistically significant values
\end{tabular}

Based on retrospective analysis of applied antiretroviral therapies and their influence on renal function, eight patients were selected from the examined patient group. They had been receiving TDF-containing regimens in 2011, but in the 2018 analysis they were receiving other antiretrovirals (abacavir/lamivudine, darunavir/ritonavir, or dolutegravir). Urine excretions of RBP, NGAL, and $\beta_{2} \mathrm{M}$ were also compared at these time points, and they were lower in the 2018 analysis compared to 2011. Additionally, only minor eGFR reduction and serum creatinine increase was noted (Table 4 ). No statistically significant differences were observed.

To compare RBP, NGAL, and $\beta_{2} \mathrm{M}$ excretion depending on renal function the patients were divided into two groups. Group I consisted of 13 patients with normal eGFR $\left(>90 \mathrm{ml} / \mathrm{min} / 1.73 \mathrm{~m}^{2}\right)$ and mean age of 48 years. Group II consisted of 21 patients with mild $\left(60-89 \mathrm{ml} / \mathrm{min} / 1.73 \mathrm{~m}^{2}\right)$ or severe $\left(<60 \mathrm{ml} / \mathrm{min} / 1.73 \mathrm{~m}^{2}\right)$ eGFR decrease (mean 
Table 3. Mean concentrations of protein markers in urine, serum creatinine, and eGFR divided by groups

\begin{tabular}{|c|c|c|c|c|c|}
\hline & $\begin{array}{c}\text { Creatinine } \\
(\mathrm{mg} / \mathrm{dl})\end{array}$ & $\begin{array}{c}\text { eGFR } \\
\left(\mathrm{ml} / \mathrm{min} / 1.73 \mathrm{~m}^{2}\right)\end{array}$ & $\begin{array}{c}\text { RBP } \\
\text { (ng/mg cr.) }\end{array}$ & $\begin{array}{c}\text { NGAL } \\
\text { (ng/mg cr.) }\end{array}$ & $\begin{array}{c}\boldsymbol{\beta}_{2} \mathrm{M} \\
(\mu \mathrm{g} / \mathrm{mg} \mathrm{cr} .)\end{array}$ \\
\hline \multicolumn{6}{|c|}{ Group I - TDF or TAF } \\
\hline$x$ & 0.97 & 87.78 & 81.89 & 17.17 & 0.53 \\
\hline SD & 0.16 & 12.31 & 61.73 & 13.49 & 1.18 \\
\hline$n$ & 22 & 22 & 22 & 22 & 22 \\
\hline \multicolumn{6}{|c|}{ Group II - other medications } \\
\hline$x$ & 1.11 & 72.18 & 219.14 & 26.10 & 1.21 \\
\hline SD & 0.24 & 18.38 & 193.65 & 34.38 & 1.92 \\
\hline$n$ & 12 & 12 & 12 & 12 & 12 \\
\hline
\end{tabular}

Table 4. Urinary LMWP concentration, serum creatinine, and eGFR in patients switched from TDF-based regimens

\begin{tabular}{|c|c|c|c|c|c|}
\hline & $\begin{array}{l}\text { Creatinine } \\
\text { (mg/dl) }\end{array}$ & $\begin{array}{c}\text { eGFR } \\
\left(\mathrm{ml} / \mathrm{min} / 1.73 \mathrm{~m}^{2}\right)\end{array}$ & $\begin{array}{c}\text { RBP } \\
\text { (ng/mg cr.) }\end{array}$ & $\begin{array}{c}\text { NGAL } \\
\text { (ng/mg cr.) }\end{array}$ & $\begin{array}{c}\boldsymbol{\beta}_{2} \mathbf{M} \\
(\mu \mathrm{g} / \mathrm{mg} \mathrm{cr} .)\end{array}$ \\
\hline \multicolumn{6}{|c|}{2011} \\
\hline$X$ & 1.18 & 75.15 & 286.89 & 29.38 & 2.20 \\
\hline SD & 0.32 & 16.95 & 147.79 & 14.72 & 2.05 \\
\hline$n$ & 8 & 8 & 8 & 8 & 8 \\
\hline \multicolumn{6}{|c|}{2018} \\
\hline$x$ & 1.23 & 63.75 & 247.63 & 15.39 & 1.71 \\
\hline SD & 0.17 & 9.01 & 195.67 & 17.79 & 2.21 \\
\hline$n$ & 8 & 8 & 8 & 8 & 8 \\
\hline
\end{tabular}

Table 5. Urine concentration of protein biomarkers stratified by eGFR

\begin{tabular}{|c|c|c|c|c|}
\hline & $\begin{array}{c}\text { eGFR } \\
\left(\mathrm{ml} / \mathrm{min} / 1.73 \mathrm{~m}^{2}\right)\end{array}$ & $\begin{array}{c}\text { RBP } \\
\text { (ng/mg cr.) }\end{array}$ & $\begin{array}{c}\text { NGAL } \\
\text { (ng/mg cr.) }\end{array}$ & $\begin{array}{c}\boldsymbol{\beta}_{2} M \\
(\mu \mathrm{g} / \mathrm{mg} \text { cr. })\end{array}$ \\
\hline \multicolumn{5}{|c|}{ Group I - eGFR > $90 \mathrm{ml} / \mathrm{min} / 1.73 \mathrm{~m}^{2}$} \\
\hline$x$ & $>90$ & 103.61 & 15.47 & 0.25 \\
\hline SD & - & 67.36 & 13.80 & 0.22 \\
\hline$n$ & 13 & 13 & 13 & 13 \\
\hline \multicolumn{5}{|c|}{ Group II - eGFR $<90 \mathrm{ml} / \mathrm{min} / 1.73 \mathrm{~m}^{2}$} \\
\hline$x$ & 71.30 & 146.88 & 23.32 & 1.09 \\
\hline SD & 10.43 & 168.72 & 27.07 & 1.83 \\
\hline$n$ & 21 & 21 & 21 & 21 \\
\hline
\end{tabular}

eGFR - $71.3 \mathrm{ml} / \mathrm{min} / 1.73 \mathrm{~m}^{2}$ ) and mean age of 52 years. The results are shown in Table 5.

Despite higher urine LMWP concentrations in the group with decreased eGFR, differences between these groups were not statistically significant. The biggest difference was seen for $\beta_{2} M$, its concentration was four-times higher in the group with decreased eGFR compared to the group with normal eGFR. Additionally, in patients with decreased eGFR statistically significant negative correlation between eGFR and $\operatorname{RBP}(R=-0.542 ; p=0.011)$ was observed. In the group of 21 patients with decreased eGFR, 50\% had normal results of this parameter in 2011. LMWP concentrations were compared between 2011 and 2018. NGAL and $\beta_{2} \mathrm{M}$ urine levels increased during the seven years, from $28.65 \mathrm{ng} / \mathrm{mg} \mathrm{cr}$. and $0.64 \mu \mathrm{g} / \mathrm{mg}$ cr. (2011) to $32.23 \mathrm{ng} / \mathrm{mg}$ cr. and $0.73 \mu \mathrm{g} / \mathrm{mg} \mathrm{cr}$. (2018), respectively.

Additionally, we analysed the influence of coinfection of HCV on the levels of examined protein parameters. Among 34 patients who were positive for anti-HCV antibodies, 17 of them were included in group I, and the rest, with 
negative results, were included in group II. In both groups serum creatinine concentrations were similar: $1.05 \mathrm{mg} / \mathrm{dl}$ in group I and $0.98 \mathrm{mg} / \mathrm{dl}$ in group II, as well as urine concentrations of RBP (130.8 ng/mg cr. and $129.87 \mathrm{ng} / \mathrm{mg}$ cr., respectively). Levels of $\beta_{2} \mathrm{M}$ were higher in $\mathrm{HCV}$-positive patients $(0.97 \mu \mathrm{g} / \mathrm{mg} \mathrm{cr}$.) compared with the negative controls $(0.57 \mu \mathrm{g} / \mathrm{mg} \mathrm{cr}$.). Retrospective analysis of protein levels in $\mathrm{HCV}$-infected patients showed large differences only in two patients. Between 2011 and 2018 RBP levels increased significantly from $12.66 \mathrm{ng} / \mathrm{mg} \mathrm{cr}$. in 2011 to $44.15 \mathrm{ng} / \mathrm{mg} \mathrm{cr}$. in 2018, and NGAL levels increased from $17.71 \mathrm{ng} / \mathrm{mg} \mathrm{cr}$. in 2011 to $21.52 \mathrm{ng} / \mathrm{mg}$ cr. in 2018.

LMWP concentrations were analysed also against route of infection (MSM, IDU, HTX). The highest concentrations were seen in patients who were infected through intravenous drug use (Table 6).

To compare urine excretion of LMWP among different T CD4(+) lymphocyte counts the patients were divided into two groups. The first group consisted of $28 \mathrm{pa}-$ tients with T CD4(+) lymphocyte count above 500 cells/ $\mu \mathrm{l}$ (mean 780 cells $/ \mu \mathrm{l}$ ). The second group included six patients with T CD4(+) lymphocyte count below 500 cells/ $\mu$ (mean 428 cells $/ \mu \mathrm{l})$. In group I the concentration of RBP and $\beta_{2} \mathrm{M}$ was: $123.83 \mathrm{ng} / \mathrm{mg} \mathrm{cr}$. and $0.62 \mu \mathrm{g} / \mathrm{mg}$ cr., respectively, and in group II it was: RBP $-160.69 \mathrm{ng} / \mathrm{mg} \mathrm{cr} ., \beta_{2} \mathrm{M}-1.45 \mu \mathrm{g} / \mathrm{mg} \mathrm{cr}$. Higher excretion of $\beta_{2} \mathrm{M}$ and $\mathrm{RBP}$ was seen in the second group; however, the differences were not statistically significant. In 11 patients the T CD4(+) count increased from the mean value of 352 cells/ $\mu \mathrm{l}$ (2011) to 765 cells/ $\mu \mathrm{l}$ (2018) in the seven-year follow-up. In this subset of patients, urine protein excretion was lower than in 2011 (Table 7).

\section{Discussion}

Our own results have not shown renal function deterioration in the seven-year follow-up period observation. Mean values of urinary levels of RBP, NGAL, and $\beta_{2} M$ in the current analysis were found to be lower than in the 2011 results. However, compared to HIV-negative controls they were significantly elevated, which is an important risk factor for renal toxicity. Additionally, statistically important correlation $(R=0.5722)$ between RBP in 2011 and 2018 shows that its concentration in urine is elevated in the same group of patients. Retinol binding protein is thought to be a better biomarker for renal dysfunction than $\beta_{2} \mathrm{M}$ or NGAL, due to its stability in urine as well as the fact that its excretion in the urine is affected only by the appearing renal dysfunction. This has been confirmed in a 10 -year observational cohort of patients with glomerular dysfunction conducted by Kirsztajn et al. [28]. They showed that high urine concentrations of RBP have high specificity to identify patients with progressive loss of renal function, while concentration above $1 \mathrm{mg} / \mathrm{l}$ was an effective and independent marker for bad prognosis, despite normal serum creatinine and creatinine clearance values.

Our study showed higher levels of analysed biomarkers in patients treated with tenofovir-sparing regimens. The re-
Table 6. Urine LMWP levels and serum creatinine in patients with different routes of infection

\begin{tabular}{l|c|c|c|c}
\hline & $\begin{array}{c}\text { Creatinine } \\
(\mathrm{mg} / \mathrm{dl})\end{array}$ & $\begin{array}{c}\text { RBP } \\
(\mathrm{ng} / \mathrm{mg} \text { cr. })\end{array}$ & $\begin{array}{c}\text { NGAL } \\
(\mathrm{ng} / \mathrm{mg} \text { cr. })\end{array}$ & $\begin{array}{c}\boldsymbol{\beta}_{2} \mathbf{M} \\
(\mu \mathrm{g} / \mathrm{mg} \text { cr. })\end{array}$ \\
\hline \multicolumn{5}{|c}{ Group I (MSM) } \\
\hline $\mathrm{X}$ & 0.99 & 93.99 & 19.91 & 0.46 \\
\hline $\mathrm{SD}$ & 0.21 & 69.01 & 12.40 & 0.82 \\
\hline$n$ & 12 & 12 & 12 & 12 \\
\hline $\mathrm{5}$ & 1.04 & 156.85 & 23.21 & 1.03 \\
\hline SD & 0.22 & 157.50 & 30.37 & 1.98 \\
\hline$n$ & 16 & 16 & 16 & 16 \\
\hline \multicolumn{5}{|c}{ Group III (HTX) } \\
\hline$X$ & 0.91 & 132.32 & 13.41 & 0.67 \\
\hline SD & 0.16 & 193.49 & 17.26 & 0.99 \\
\hline$n$ & 6 & 6 & 6 & 6 \\
\hline
\end{tabular}

Table 7. Urine LMWP excretion in the subset of patients with higher T CD4(+) lymphocyte count in 7-year follow-up

\begin{tabular}{l|c|c|c|c}
\hline & $\begin{array}{c}\text { CD4(+) } \\
\text { (cells/ } \mu \mathrm{l})\end{array}$ & $\begin{array}{c}\text { RBP } \\
(\mathrm{ng} / \mathrm{mg} \text { cr. })\end{array}$ & $\begin{array}{c}\text { NGAL } \\
(\mathrm{ng} / \mathrm{mg} \text { cr. })\end{array}$ & $\begin{array}{c}\boldsymbol{\beta}_{2} \mathrm{M} \\
(\mu \mathrm{g} / \mathrm{mg} \text { cr. })\end{array}$ \\
\hline $\mathrm{5}$ & 352 & 159.67 & 24.01 & 0.49 \\
\hline $\mathrm{SD}$ & 127 & 160.56 & 17.17 & 0.44 \\
\hline$n$ & 11 & 11 & 11 & 11 \\
\hline \multicolumn{5}{|c|}{2011} \\
\hline $\mathrm{X}$ & 765 & 78.03 & 15.50 & 0.29 \\
\hline $\mathrm{SD}$ & 149 & 37.46 & 13.57 & 0.25 \\
\hline$n$ & 11 & 11 & 11 & 11 \\
\hline
\end{tabular}

sults are discrepant to the ones from 2011 in which urine protein excretion was higher in patients treated with tenofovir. Similarly, Lee et al. [29] in their retrospective study did not show higher rates of renal dysfunction in patients treated with tenofovir compared to other regimens. Frequent medical check-ups and monitoring of renal function performed as part of antiretroviral therapy allow rapid intervention and CART regimen changes as required. Introducing for the treatment of a new tenofovir prodrug, tenofovir alafenamide, proved to be an important factor. It had been shown to be less nephrotoxic than TDF. Up to $86 \%$ of the analysed patients receiving tenofovir were treated with TAF. Its lesser renal toxicity may be the reason for lower protein excretion with urine in the current analysis. Cattaneo et al. [30] also showed improvement in renal function after switching from TDF-based to TAF-based regimens. Comparing these two drugs, they showed lesser changes in renal dysfunction markers both in serum and in urine in patients receiving 
TAF-based regimens. Similarly, DeJesus et al. [31] in their 96-week observation showed improvement in serum creatinine and urine excretion of proteins after switching from TDF to TAF. Rate of HIV suppression remained unchanged. We postulate that the introduction of the new prodrug into cART regimens improved renal function in our patients.

We also showed positive correlation $(R=0.6325)$ between serum creatinine levels and $\beta_{2} M$ in urine in patients receiving tenofovir-sparing regimens containing most commonly abacavir, lamivudine and darunavir/r or dolutegravir. Ritonavir can cause nephrotoxicity itself [7] as well as increase levels of other medications used concomitantly. Spiegel et al. [32] described a case of acute renal failure in a patient receiving abacavir. Serum creatinine levels reflect renal function, and the positive correlation between $\beta_{2} \mathrm{M}$ and serum creatinine shown in our study confirms its usefulness.

Our study also included patients switched from tenofovir-based regimens in 2011 to other regimens. In this group, the biomarker levels decreased and serum creatinine as well as eGFR values improved. This suggests that tenofovir may be nephrotoxic. We also showed different levels of LMWP excretion in urine in patients with normal and decreased eGFR. Although in patients with decreased eGFR $\left(<90 \mathrm{ml} / \mathrm{min} / 1.73 \mathrm{~m}^{2}\right)$ they were not statistically significantly higher, $\beta_{2} \mathrm{M}$ levels were four-times higher compared to patients with normal eGFR. Additionally, statistically significant negative correlation was shown between eGFR values and RBP concentration in patients with decreased eGFR. This negative correlation confirms its usefulness in renal function disorders. Campbell et al. [33] showed 50\% increase in RBP urine excretion in patients with decreased eGFR receiving tenofovir-based cART.

We did not show statistically significant differences in the protein biomarker levels depending on HCV coinfection. However, higher $\beta_{2} \mathrm{M}$ concentrations were seen in patients positive for $\mathrm{HCV}$ antibodies. Similar observations were made by Oboho et al. [34], who showed increased $\beta_{2} \mathrm{M}$ excretion in women co-infected with HIV and HCV. Such coinfection usually exacerbates renal disease. Canadian researchers showed faster progression to renal insufficiency in patients co-infected with HIV and HCV [35]. Our retrospective analysis of protein concentrations showed increase only in two patients in 2018.

We also analysed LMWP excretion with urine depending on the route of HIV infection. The highest values of examined biomarkers were seen in patients infected through intravenous drug use. The high concentrations in this group may be the result of substance use. Adebamiro et al. [36] showed that synthetic cathinones can negatively influence renal function, leading to renal ischaemia. There are no data about how recreational substance use influences urine excretion of low molecular weight proteins or serum creatinine levels. Our study also showed higher protein concentrations in urine in patients with lower T CD4(+) cell counts, which can be explained by increased risk of exposure to additional factors, including nephrotoxic ones. The number of T CD4(+) cells increased in 2018 compared to 2011, and the amount of protein excreted with urine decreased, which suggests an association between immune function, HIV progression, and renal dysfunction.

This retrospective analysis of renal function can be a valuable insight for clinicians. However, results obtained at such distant time periods cannot be the basis for the unequivocal conclusion that cART is nephrotoxic, including tenofovir. Recent TAF introduction can be an important factor responsible for improvement in measured parameters because TAF was shown in other studies to be less nephrotoxic than TDF.

\section{Conclusions}

In our analysis, we distinctly showed the overlapping influence of different factors as well as individual predispositions on renal dysfunction in HIV-infected patients. The retrospective analysis showed the usefulness of measurement of low molecular weight protein concentrations in urine for renal function evaluation in these patients as well as in the analysis of different factors influencing disease progression. The studied protein biomarkers can help diagnose renal micro-damage and start efficacious protective measures early, preventing renal insufficiency.

A limitation of this study is the small number of patients due to change of HIV clinic, death, or other unknown factors. HCV viral load measurement was not performed, which did not allow us to discern patients with ongoing replication. Further study is need with larger numbers of patients, which will give a wide view on the usefulness of these biomarkers as prognostic factors of renal function in HIV-infected patients.

\section{Conflict of interest}

The authors declare no potential conflicts of interest with respect to the research, authorship, and/or publication of this article.

\section{References}

1. Gładysz A, Knysz B. Zakażenia HIV i AIDS - poradnik dla lekarzy. Wydawnictwo Continuo, Wrocław 2014; 109-125.

2. Marchewka Z, Szymańska B, Szymanek-Pasternak A, et al. Przydatność oznaczania aktywności wybranych enzymów w moczu w ocenie uszkodzenia funkcji nerek u pacjentów zakażonych HIV poddanych terapii antyretrowirusowej. Diagn Lab 2014; 50: 227-234.

3. Horban A, Podlasin R, Cholewińska G, et al. Zasady opieki nad osobami zakażonymi HIV. Pol Tow Nauk AIDS, Warszawa-Szczecin 2018; 397-407, 408-415.

4. Qadir MI. Hepatitis in AIDS patients. Rev Med Virol 2017; 28 : 1956-1963.

5. Sikavi C, Chen PH, Lee AD, et al. Hepatitis C and Human Immunodeficiency Virus Co-Infection in the Era of Direct-Acting Antiviral Agents: No Longer A Difficult to Treat Population. Hepatology 2017; 67: 847-857.

6. Bertoldi A, De Crignis E, Re MC, et al. HIV and kidney: a dangerous liaison. New Microbiol 2017; 40: 1-10.

7. Röling J, Schmid H, Fischereder M, et al. HIV-Associated Renal Diseases and Highly Active Antiretroviral Therapy Induced Nephropathy. Clin Infect Dis 2006; 42: 1488-1495. 
8. Horban A, Podlasin R, Cholewińska G, et al. Zasady opieki nad osobami zakażonymi HIV. Zalecenia PTN AIDS. PTN AIDS, Warszawa-Wrocław 2016; 376-384.

9. Jin A, Boroujerdi-Rad L, Shah G, Chen JL. Thrombotic microangiopathy and human immunodeficiency virus in the era of eculizumab. Clin Kidney J 2016; 9: 576-579.

10. Weiner NJ, Goodman JW, Kimmel PL. The HIV-associated renal diseases: current insight into pathogenesis and treatment. Kidney Int 2003; 63: 1618-1631.

11. Ross MJ. Advances in the pathogenesis of HIV-associated kidney diseases. Kidney Int 2014; 86: 266-274.

12. Butt AA, McGinnis K, Rodriguez-Barradas MC, et al. HIV Infection and the Risk of Diabetes Mellitus. AIDS 2009; 23: 1227-1234.

13. Campos P, Ortiz A, Soto K. HIV and kidney diseases: 35 years of history and consequences. Clin Kidney J 2016; 9: 772-781.

14. Marchewka Z, Szymczak A, Knysz B. Choroby współistniejące jako czynniki ryzyka przewlekłej choroby nerek u osób zakażonych HIV. Postepy Hig Med Dosw 2015; 69: 1364-1370.

15. Adebamiro A, Perazella MA. Recurrent acute kidney injury following bath salts intoxication. Am J Kidney Dis 2012; 59: 273-275.

16. Gładysz A, Knysz B. Diagnostyka, profilaktyka, klinika i terapia zakażeń HIV/AIDS - współczesne możliwości i problemy. Wydawnictwo Continuo, Wrocław 2009; 157-165.

17. Marchewka Z, Szymańska B, Szymanek-Pasternak A, et al. Przydatność oznaczania aktywności wybranych enzymów w moczu w ocenie uszkodzenia funkcji nerek u pacjentów zakażonych HIV poddanych terapii antyretrowirusowej. Diagn Lab 2014; 50: 227-234.

18. Marchewka Z. Niskocząsteczkowe wskaźniki biochemiczne w diagnostyce nefrotoksyczności. Adv Clin Exp Med 2006; 15: 1129-1138.

19. Shyam R, Patel ML, Sachan R, et al. Role of Urinary Neutrophil Gelatinase-associated Lipocalin as a Biomarker of Acute Kidney Injury in Patients with Circulatory Shock. Indian J Crit Care Med 2017; 21: 740-745.

20. Mårtensson J, Bellomo R. The rise and fall of NGAL in acute kidney injury. Blood Purif 2014; 37: 304-310.

21. Varnell CD, Goldstein SL, Devarajan P, Basu RK. Impact of Near Real-Time Urine Neutrophil Gelatinase-Associated Lipocalin Assessment on Clinical Practice. Kidney Int Rep 2017; 2: 1243-1249.

22. Lisowska-Myjak B, Skarżyńska E, Wilczyńska P, Jakimiuk A. Correlation between the concentrations of lactoferrin and neutrophil gelatinase-associated lipocalin in meconium. Biometals 2018; 31: 123-129.

23. Haase-Fielitz A, Haase M, Devarajan P. Neutrophil gelatinaseassociated lipocalin as a biomarker of acute kidney injury: a critical evaluation of current status. Ann Clin Biochem 2014; 51: 335-351.

24. Sola-Del Valle DA, Mohan S, Cheng JT, et al. Urinary NGAL is a useful clinical biomarker of HIV-associated nephropathy. Nephrol Dial Transplant 2011; 26: 2387-2390.

25. Argyropoulos CP, Chen SS, Ng YH, et al. Rediscovering Beta-2 Microglobulin As a Biomarker across the Spectrum of Kidney Diseases. Front Med (Lausanne) 2017; 4: 73-98.

26. Tian F, Wang ZB, Meng DM, et al. Preliminary study on the role of virtual touch tissue quantification combined with a urinary $\beta 2$-microglobulin test on the early diagnosis of gouty kidney damage. Ultrasound Med Biol 2014; 40: 1394-1399.

27. Norden AG, Lapsley M, Unwin RJ. Urine Retinol Binding Protein 4: A Functional Biomarker of the Proximal renal Tubule. Adv Clin Chem 2014; 63: 85-122.

28. Kirsztajn GM, Nishida SK, Silva MS, et al. Urinary retinol-binding protein as a prognostic marker in glomerulopathies. Nephron 2002; 90: 424-431.

29. Lee JE, Lee $\mathrm{S}$, Song $\mathrm{SH}$, et al. Incidence and risk factors for tenofovir-associated nephrotoxicity among human immunodeficiency virus-infected patients in Korea. Korean J Intern Med 2017; http:// kjim.org/journal/view.php?doi=10.3904/kjim.2016.418 (accessed: 13 December 2017).
30. Cattaneo D, Minisci D, Baldelli S, et al. Effect of Cobicistat on Tenofovir Disoproxil Fumarate (TDF): What Is True for TAF May Also Be True for TDF. J Acquir Immune Defic Syndr 2018; 77: 86-92.

31. DeJesus E, Haas B, Segal-Maurer S, et al. Superior Efficacy and Improved Renal and Bone Safety After Switching from a TenofovirDisoproxil Fumarate- to a Tenofovir Alafenamide-Based Regimen Through 96 Weeks of Treatment. AIDS Res Hum Retroviruses 2018; 34: 337-342.

32. Spiegel LR, Schrier PB, Shah HH. Severe recurrent rhabdomyolysisinduced acute kidney injury in a HIV-infected patient on antiretroviral therapy. Ren. Fail 2013; 35: 1186-1190.

33. Campbell LJ, Dew T, Salota R, et al. Total protein, albumin and low-molecular-weight protein excretion in HIV-positive patients. BMC Nephrol 2012; 13: 85.

34. Oboho I, Abraham A, Benning L, et al. Tenofovir use and urinary biomarkers among HIV-infected women in the Women's Interagency HIV Study (WIHS). J Acquir Immune Defic Syndr 2013; 62: 388-395.

35. Rossi C, Raboud J, Walmsley S, et al. Hepatitis C co-infection is associated with an increased risk of incident chronic kidney disease in HIV-infected patients initiating combination antiretroviral therapy. BMC Infect Dis 2017; 17: 246-247.

36. Adebamiro A, Perazella MA. Recurrent acute kidney injury following bath salts intoxication. Am J Kidney Dis 2012; 59: 273-275. 